\title{
The Role of the Natural Antioxidant Mechanism in Sperm Cells
}

\author{
Alicja Kowalczyk ${ }^{1}$ (1)
}

Received: 14 March 2021 / Accepted: 3 November 2021 / Published online: 29 November 2021

(c) The Author(s) 2021

\begin{abstract}
Molecular studies of the causes of male infertility revealed a significant contribution of oxidative stress. When excessive amounts of reactive oxygen species (ROS) are produced or antioxidant activity fails, the equilibrium between oxidation and reduction is disrupted, causing oxidative stress (OS). High levels of ROS can have an adverse effect on sperm function through the initiation of DNA damage, lipid peroxidation, loss of membrane integrity and increased permeability, inactivation of cellular enzymes, and cell apoptosis. In addition to endogenous factors such as immature sperm, leukocytes, and varicocele, potential causes of excessive ROS can also be found exogenously in males with testicular hyperthermia or exposed to environmental toxicity. To maintain the optimal functioning of sperm cells, it is, therefore, necessary to balance the redox potential, i.e., to balance ROS by antioxidants. The purpose of this review is to present the antioxidant defense systems in semen.
\end{abstract}

Keywords Antioxidants $\cdot$ Cell $\cdot$ Mechanism $\cdot$ Spermatozoa $\cdot$ Reproduction

$\begin{array}{ll}\text { Abbreviations } \\ \text { APX } & \text { Ascorbate peroxidase } \\ \text { CT } & \text { Catalase } \\ \text { ROS } & \text { Reactive oxygen species } \\ \text { OS } & \text { Oxidative stress } \\ \text { SOD } & \text { Superoxide oxidoreductases } \\ \text { GPX } & \text { Glutathione peroxidase } \\ \text { CoQ10 } & \text { Coenzyme Q10 } \\ \text { PHGPX } & \text { Phospholipid hydroperoxide glutathione } \\ & \text { peroxidase } \\ \text { NAC } & \text { N-acetyl cysteine } \\ \text { LPO } & \text { Lipid peroxidation }\end{array}$

\section{Introduction}

Molecular studies of the underlying causes of male infertility have revealed a significant share of oxidative stress (OS), which is defined as an imbalance in the redox state of the body caused either by too high levels of oxidants or, conversely, by too little antioxidants. When excessive amounts of reactive oxygen species (ROS) are produced or

Alicja Kowalczyk

alicja.kowalczyk@upwr.edu.pl

1 Department of Environment Hygiene, and Animal Welfare, Wrocław University Of Environmental and Life Sciences, Chełmońskiego 38C, Wroclaw, Poland antioxidant activity fails, the equilibrium between oxidation and reduction is disrupted, causing oxidative stress (OS). Sperm are especially sensitive to OS. They contain very low levels of enzymatic antioxidants which are insufficient to protect sperm from high levels of ROS, and the cytoplasm has only small concentrations of the enzyme capable of neutralizing them. A growing body of evidence suggests that the imbalance between oxidants and antioxidants in semen leads to metabolic and functional disorders of male reproductive cells and may be the main cause of some types of infertility [1]. The oxygen metabolism of human sperm produces various potentially harmful ROS on the plasma membrane of sperm with a high content of polyunsaturated fatty acids $[2,3]$. ROS are divided into oxygen radicals (hydroxyl radical, nitric oxide radical, and superoxide anion radical) and nonradical derivatives (hydrogen peroxide, peroxynitrite anion, and hypochlorous acid) [4]. Sperm produce them in very small amounts, providing beneficial functional effects, including the initiation of sperm capacitation, regulation of sperm maturation, and enhancement of cell signaling pathways [5]. Moreover, ROS are involved in the condensation of sperm chromatin, regulating the number of reproductive cells by inducing apoptosis or proliferation of spermatogonia [6]. On the other hand, high levels of ROS may have an adverse effect on sperm function through the initiation of DNA damage, lipid peroxidation, loss of membrane integrity, increased membrane permeability, inactivation of cellular enzymes, and cell apoptosis [7-9] ultimately leading 
to infertility [10]. DNA damage caused by oxidation breaks the chromosome, leading to mutations [11]. Single strand lesions, and in particular DNA double strand breaks, are the most genotoxic and irreparable lesions [12]. It has been shown that sperm DNA integrity may be irreversibly compromised in response to increased susceptibility to OS [13]. Several studies have confirmed the important role of intact sperm DNA in normal embryonic development [14-16]. According to Virro et al. [17], moreover, it has been shown that changes in the paternal genome can influence the development of embryos even with direct injection of semen into the oocyte via ICSI. Other researchers have found that higher levels of DNA fragmentation in sperm are associated with lower rates of blastocyst formation [17]. Nasr-Esfahani et al. [18] showed that sperm-derived embryos with high levels of DNA damage are less likely to reach later developmental stages or blastocysts. Moreover, the fragmentation of sperm DNA showed a negative correlation with the rates of blastulation and pregnancy even in the case of good quality oocytes, and high levels of DNA damage favored the arrest of embryo development [19].

We distinguish at least three main sources of ROS in semen: the membrane NADPH oxidase, an enzyme complex contained in the cell membrane, and the others are mitochondria. It was also found that the production of superoxide anions involves NADH oxidoreductase (diaphorase), an enzyme located in the middle part of the sperm, which is closely related to the mitochondrial chain and xanthine oxidase present in both semen and semen plasma [20]. The third source is leukocytes, which under physiological conditions produce up to 1000 times more ROS than sperm [21]. It is worth emphasizing that sperm with abnormal morphology (mainly with cytoplasmic residues indicating their immaturity and reduced fertility potential) produce greater amounts of ROS than sperm with normal structure [22, 23]. There is also a difference in the amount of ROS produced by sperm at different stages of maturation. Apart from endogenous factors, such as immature sperm, leukocytes, and varicocele, potential causes can also be sought exogenously in males with testicular hyperthermia or those exposed to environmental toxicity.

To maintain the optimal functioning of sperm cells, it is, therefore, necessary to balance the redox potential, i.e., to balance ROS by antioxidants [24]. Seminal fluid is rich in them and at the same time performs nutritional and protective functions for sperm. Antioxidants can be divided into two forms: enzymatic and non-enzymatic antioxidant systems [25]. The enzyme system consists of glutathione peroxidase, superoxide dismutase, and catalase. These enzymes occur naturally in sperm or semen plasma and are thought to come from the prostate. On the other hand, the non-enzymatic system consists of many compounds that are delivered to the body with food (including dietary supplements).
The purpose of this review is to present the antioxidant defense systems in semen.

\section{Antioxidant Enzymes}

The major system of antioxidant enzymes in semen is called the enzyme triad of superoxide dismutase, catalase, and glutathione peroxidase.

Catalysts for the dismutation of superoxide anions include superoxide dismutases or superoxide oxidoreductases. Two forms of their intra- and extracellular occurrence have been identified. Two of the intracellular forms are copper-zinc SOD, which is located mainly in the cytoplasm and contains, as the name suggests, the elements copper and zinc $(\mathrm{Cu}, \mathrm{ZnSOD}, \mathrm{SOD}-1)$ in the active center and SOD manganese, which is mainly located in the mitochondrial matrix (MnSOD, SOD-2) with manganese in the active center. The extracellular form of SOD (EC-SOD, SOD-3) located in the extracellular space is structurally similar to SOD-2, but instead of manganese, it has zinc and copper in its active center $[20,26]$. SOD is highly active in semen plasma, with $75 \%$ of its activity related to SOD-1 activity and the remaining $25 \%$ to SOD-3. It has been shown that these two isoenzymes probably originate from the prostate [27].

Catalase (CT) in turn catalyzes the decomposition of hydrogen peroxide into molecular oxygen and water. Characteristic for $\mathrm{CT}$ is the heme system with a centrally located iron atom. Its activity has been demonstrated in peroxisomes, mitochondria, endoplasmic reticulum, and cytosol in various cells [28]. In the ejaculate, it has been located in human and rodent sperm, and in semen plasma, the source of which is the prostate [20]. Catalase is involved in the activation of sperm capacitation induced by nitric oxide, which is a complicated mechanism of hydrogen peroxide [29].

The enzyme catalyzing the reduction of hydrogen peroxide and organic peroxides, including peroxides of phospholipids in the antioxidant system in semen, is glutathione peroxidase (GPX) [30]. In its active place, it contains selenium in the form of selenocysteine. In sperm, it is located mainly in the mitochondrial matrix [27], but a nuclear form has also been found, which has a protective effect on sperm DNA against OS damage and is actively involved in the chromatin condensation process [31]. The presence of GPX was also demonstrated in semen plasma, which suggests its origin also from the prostate, as well as the enzymes mentioned above [32].

The complex spatial structure of enzyme molecules determines both the catalytic capabilities and the sensitivity to many environmental factors. The basic mechanism of enzyme action is related to the spatial adjustment of the substrate to the catalytic center of the enzyme. 


\section{Non-enzymatic Antioxidants}

There are also non-enzymatic antioxidants in the cell, which also play a key role in protecting sperm cells from OS. Table 1 shows the main antioxidants belonging to the non-enzyme and enzyme groups, along with their location and function.

The group of non-enzymatic antioxidants also includes coenzyme Q10, which is especially present in high concentrations in the mitochondria of sperm involved in cell respiration and plays an integral role in energy production [39]. This positive effect promotes its use as a motility stimulant and antioxidant molecule. Interestingly, CoQ10 inhibits the formation of superoxide, providing protection against OS-induced sperm dysfunction. There was a significant negative correlation between CoQ10 levels and hydrogen peroxide, and a linear correlation was found between CoQ10 levels with the sperm count in the semen and their motility [40].

Selenium shows the ability to protect sperm DNA against OS damage in a mechanism that has not yet been well understood. Since selenium is the main component of selenoenzymes, its antioxidant properties are thought to stem from its ability to augment the function of glutathione. More than 25 selenoproteins exist, such as phospholipid hydroperoxide glutathione peroxidase (PHGPX) [41] and sperm capsular selenoprotein glutathione peroxidase [42], which help maintain sperm structural integrity [43]. Selenium deficiency has been most commonly associated with morphological sperm midpiece abnormalities and impairment of sperm motility [44].

The action of all antioxidants in the body ultimately comes down to counteracting the effects of oxidation processes, whether directly by catalyzing enzymatic reactions or indirectly as compounds that deactivate free radicals and stop the cascade of chain reactions. The antioxidant systems undoubtedly also include groups of compounds participating in the constant restoration of the antioxidant potential, because all molecules participating in the reactions are consumed and must be restored [27].

Due to the lack of part of the cytoplasm, mammalian sperm cells have a reduced ability of antioxidant defense, which makes them less resistant to oxidative damage [45]. Thus, the presence of antioxidant enzymes in semen is extremely important to prevent the negative effects of OS during sperm storage. The addition of natural antioxidants to dilute the semen has become necessary due to the lack of sufficient natural antioxidant reserves to maintain the satisfactory biological potential of the sperm. Plant-derived and synthetic compounds are widely used in sperm preservation technology of various species and are currently considered a valuable source of antioxidants, mainly due to the lack or low incidence of side effects [46-50].

\section{Methods of Supporting the Natural Antioxidant System}

Antioxidants are widely available compounds that are commonly used in the treatment of male infertility. The main division of methods focuses on oral therapy and sperm supplementation. Many studies report a beneficial effect of antioxidant therapy on the basic biological parameters of semen, advanced sperm function, the results of assisted reproductive therapy, and the live birth rate $[51,52]$. The most commonly tested antioxidants and their doses were as follows: $\alpha$-tocopherol $(400 \mathrm{mg})$, ascorbic acid (500-1000 $\mathrm{mg}$ ), carnitine (500-1000 mg), N-acetyl cysteine (NAC; $600 \mathrm{mg}$ ), coenzyme Q10 (CoQ10, 100-300 mg) zinc (Zn) $(25-400 \mathrm{mg})$, selenium $(\mathrm{Se})(200 \mu \mathrm{g})$, folic acid $(0.5 \mathrm{mg})$, and lycopene $(6-8 \mathrm{mg})$ [81-86].

\section{a-Tocopherol (Vit. E)}

$\alpha$-Tocopherol (Vit. E) is a fat soluble organic compound found mainly in cell membranes. It neutralizes hydroxyl free radicals and superoxide anions, effectively inhibiting

Table 1 Location and function of major non-enzymatic and enzymatic antioxidants

\begin{tabular}{|c|c|c|c|}
\hline Antioxidants & Locations & Function & References \\
\hline Glutathione & Non-protein thiol in cell & Deactivates free radicals & {$[33-35]$} \\
\hline Carotenoids & Lipid soluble antioxidant in membrane tissue & $\begin{array}{l}\text { Maintains cell membrane integrity; regulates spermato- } \\
\text { genesis and proliferation of epithelial cells }\end{array}$ & [36] \\
\hline $\begin{array}{l}\text { Vitamin E } \\
(\alpha \text {-tocopherol) }\end{array}$ & Mostly in membranes & $\begin{array}{l}\text { Detoxifies products of membrane lipid peroxidation } \\
\text { (LPO) }\end{array}$ & {$[37,38]$} \\
\hline $\begin{array}{l}\text { Vitamin C } \\
\text { (ascorbic acid) }\end{array}$ & Cytosol, chloroplast, mitochondria, peroxisome, vacuole & Detoxifies $\mathrm{H}_{2} \mathrm{O}_{2}$. & {$[30]$} \\
\hline SOD & All eukaryotic cells & Lowers the steady-state level of $\mathrm{O}^{2-}$ & {$[20,26,27]$} \\
\hline CT & Intracellular organelles, peroxisomes & Lowers the level of $\mathrm{H}_{2} \mathrm{O}_{2}$ & {$[28,29]$} \\
\hline GPX & Cytoplasm, mitochondrial matrix & Lowers the level of $\mathrm{H}_{2} \mathrm{O}_{2}$ & {$[31,32]$} \\
\hline
\end{tabular}


lipid peroxidation initiated by ROS at the level of plasma membranes. A direct relationship was found between the level of vitamin $E$ in the semen plasma and the percentage of motile sperm in the ejaculate [53]. Moreover, Omu et al. [54] showed that infertile men sperm with significantly lower levels of vitamin E. Moreover, patients treated with vitamin E for 6 months had a much lower percentage of sperm with LPO; additionally, vitamin E may increase the pregnancy rate in cases of asthenozoospermia [55]. It has also been shown that the simultaneous administration of $\alpha$-tocopherol and selenium increases sperm motility in infertile men [56, 57]. Recent studies have shown a protective effect of vitamin E on sperm motility and oxidative stress in rats treated with valproic acid [58].

\section{Ascorbic Acid (Vit. C)}

The concentration of this compound is almost ten times higher in the semen plasma than in the blood serum [59, 80]. It neutralizes hydroxyl, superoxide, and peroxide radicals, protecting against endogenous oxidative damage [60, 80]. It has been shown that the addition of vitamin C (and vitamin $\mathrm{E}$ ) to the semen of men with normozoospermia and asthenozoospermia reduces the degree of DNA fragmentation caused by ROS [61, 62]. In turn, Akmal et al. [63] achieved an improvement in total sperm count, motility, and morphology after the administration of vitamin $\mathrm{C}$ in the dose of $2000 \mathrm{mg} /$ day.

\section{Carnitines [L-Carnitine (LC) and L-Acetyl Carnitine (Lac)]}

Carnitine is involved in the sperm maturation process in the epididymis. The concentration of free L-carnitine in the tail of the epididymis is 2,000 times higher than in the blood plasma. Carnitine is taken from the blood and then transferred to the epididymis through active epithelial pumps that are stimulated by androgens $[87,88]$. Its deficiency may lead to decreased sperm motility [89]. Many in vitro studies of sperm cultured in media containing carnitine have reported an increase in cell mobility and viability compared to controls $[64,65]$. The effectiveness of L-carnitine as an antioxidant has been observed both in humans [66] and in rats [67, 68]. More recently, Abd-Elrazek and Ahmed-Farid [69] showed that administration of L-carnitine to adult oligospermic rats attenuated the cytotoxic effect of busulfan by improving sperm parameters, reducing oxidative stress, and maintaining cellular energy. Moreover, Nazari et al. [70] proved that antioxidant supplementation containing $1500 \mathrm{mg}$ of L-carnitine can improve sperm quality in infertile men by improving cell concentration and overall motility.

\section{N-Acetylcysteine}

An amino acid converted into cysteine in tissues, a precursor to glutathione, is a compound capable of direct reduction of OS by scavenging hypochlorous acid and hydroxyl radicals [71]. Numerous studies (in vitro) showed a significant decrease in the level of ROS generation and an improvement in the motility of sperm incubated in the presence of NAC [72]. In turn, Jannatifar et al. [73] proved that NAC therapy increases the number and percentage of motile sperm, while reducing the number of sperm cells with abnormal morphology and damaged DNA. In turn, in adjunctive therapy after varicocelectomy, as reported by Barekata et al. [74], NAC may have a positive effect on chromatin integrity and pregnancy rate.

\section{Zinc}

Zinc plays an essential role in RNA and DNA metabolism, signal transduction, gene expression, and regulation of apoptosis [80]. Moreover, it has been shown that zinc has a significant protective effect on the structure of sperm. The use of zinc in asthenozoospermic patients reduces oxidative stress, apoptosis, and DNA fragmentation of their sperm $[41,75]$. Recent studies have shown that supplementation of sperm media with zinc protects bull sperm against exogenous oxidative stress and improves their ability to support embryo development [76]. Moreover, other researchers [77] reported that supplementing zinc oxide nanoparticles in the cryopreservation medium minimizes the freeze-thawinduced damage to spermatozoa.

\section{Lycopene}

Lycopene is a naturally synthesized carotenoid is found in fruits and vegetables. Its powerful ROS-extinguishing abilities make it a major contributor to the human redox defense system [78, 80]. The results of studies by Tvrda et al. [79] suggest that lycopene exhibits significant ROS-scavenging and antioxidant properties, which may prevent sperm lesions caused by oxidative stress and preserve the functionality of male reproductive cells.

\section{Limitations Related to ROS Balancing in Reproductive Medicine}

It has been a long time since the link between redox homeostasis and impaired male fertility was established. The numerous antioxidant molecules present in the male reproductive system maintain the physiological level of ROS, which allows them to stimulate almost the entire process pathway from steridogenesis to oocyte fertilization. 
Undoubtedly, the greatest challenge of reproductive medicine is the prevention of ROS-induced reproductive disorders, as well as the restoration of redox homeostasis when reproductive abnormalities are detected. Hence, antioxidant therapies represent a potential preventive and therapeutic alternative in the management of patients at risk of ROS imbalance.

Various antioxidants can have a synergistic effect on the removal of active oxygen, which was confirmed in the studies by Ren et al. [90]. This may be due to the different binding rate to active ROS and the different mode of action. Moreover, the synergistic effect of two different antioxidants has the potential to improve selected parameters of the preserved semen compared to adding only one antioxidant to the extender.

Unfortunately, there is still a lack of research providing information on the potential mechanism of antioxidant action, which delays the development of more effective and broader antioxidant therapies. Therefore, it is necessary to conduct further research in this direction to be able to determine the dosage of antioxidant supplementation, which is currently not regulated. It should be remembered that unregulated (improper) supplementation can also lead to pathological abundance of antioxidants, also causing redox dysregulation and inhibiting important reproductive processes.

Finally, a significant problem with the use of oxidative therapies is the difficulty in distinguishing between normal and abnormal ROS concentrations, which makes it difficult to accept the ROS measurement as a standard process in routine semen analysis for clinical applications.

\section{Conclusion}

The growing awareness of the factors of the pathogenesis of many diseases that the humanity of the twenty-first century has to deal with prompts us to look for mechanisms that will help to counteract these diseases and their consequences. Research in recent years has shown that oxidative stress, caused by reactive oxygen species and free radicals, can underlie the occurrence of many reproductive disorders and is directly related to infertility or complete sterility. Although the antioxidant defense system is active in semen, its activity is limited due to the low amount of sperm cytoplasm; therefore, scientists are still making efforts to search for substances that can support the natural antioxidant defense system of cells.

The therapeutic value of antioxidants depends on their ability to prevent or alleviate specific conditions. Despite their protective effect against oxidative stress, they exhibit certain features that ultimately limit their use. These limitations are their instability to oxidative processes or changes in $\mathrm{pH}$, as well as the possibility of achieving concentrations that cause an antioxidative effect. Very often, these compounds show low solubility, which requires them to be administered with solvents (such as ethanol or dimethylsulfoxide) or with high concentrations of surfactants that can lead to toxicity.

To date, many compounds with antioxidant properties have been studied for the treatment of infertile men. Understanding the antioxidant mechanism of action of commonly used compounds is important before considering the evidence related to their use in clinical practice.

Data Availability Not applicable.

\section{Declarations}

Ethics Approval and Consent to Participate Not applicable.

Consent for Publication The author consents to publish.

Competing Interests The author declares no competing interests.

Open Access This article is licensed under a Creative Commons Attribution 4.0 International License, which permits use, sharing, adaptation, distribution and reproduction in any medium or format, as long as you give appropriate credit to the original author(s) and the source, provide a link to the Creative Commons licence, and indicate if changes were made. The images or other third party material in this article are included in the article's Creative Commons licence, unless indicated otherwise in a credit line to the material. If material is not included in the article's Creative Commons licence and your intended use is not permitted by statutory regulation or exceeds the permitted use, you will need to obtain permission directly from the copyright holder. To view a copy of this licence, visit http://creativecommons.org/licenses/by/4.0/.

\section{References}

1. Fraczek M, Kurpisz M. Inflammatory mediators exert toxic effects of oxidative stress on human spermatozoa. J Androl. 2007;28:325-33.

2. Jones R, Mann T, Shering P. Peroxidative breakdown of phospholipids in human spermatozoa, spermicidal properties of fatty acid peroxides and protective action of seminal plasma. Fertil Steril. 1979;3:531-7.

3. Storey BT. Biochemistry of the induction and prevention of lipoperoxidative damage in human spermatozoa. Mol Hum Reprod. 1997;3:203-13.

4. Halliwell B. Free radicals and vascular disease: how much do we know? BMJ. 1993;307:885-6.

5. Ford CE, Jones KW, Miller OJ, Mittwoch U, Penrose LS, Ridler $\mathrm{M}$, et al. The chromosomes in a patient showing both mongolismMongolism and the Klinefelter syndrome. Lancet. 1959;1:709-10.

6. Aitken RJ. The Amoroso Lecture. The human spermatozoon-a cell in crisis? J Reprod Fertil. 1999;115:1-7.

7. Henkel R, Schill WB. Sperm separation in patients with urogenital infections. Andrologia. 1998;30(Suppl 1):91-7.

8. Sanocka-Maciejewska D, Ciupinska M, Kurpisz M. Bacterial infection and semen quality. J Reprod Immunol. 2005;67:51-6. 
9. Schuppe HC, Meinhardt A, Allam JP, Bergmann M, Weidner W, Haidl G. Chronic orchitis: a neglected cause of male infertility? Andrologia. 2008;40:84-91.

10. Hull M, Glazener C, Kelley N, Conway D, Foster P, Hunton R, Coulson C, Lambert P, Watt E, Desai K. Population study of causes, treatment and outcome of fertility. Br Med J. 1985;291:1693-7.

11. Poulsen HE, Prieme H, Loft S. Role of oxidative DNA damage in cancer initiation and promotion. Eur J Cancer Prev. 1998;7(1):9-16.

12. Brochier C, Langley B. Chromatin modifications associated with DNA doublestrand breaks repair as potential targets for neurological diseases. Neurotherapeutics. 2013;10(4):817-30.

13. Simoes R, Feitosa WB, Siqueira AFP, Nichi M, Paula-Lopes FF, Marques MG, Assumpcao MEO. Influence of bovine sperm DNA fragmentation and oxidative stress on early embryo in vitro development outcome. Reproduction. 2013;146(5):43341. https://doi.org/10.1530/rep-13-0123.

14. Fernandez JL, Muriel L, Rivero MT, Goyanes V, Vazquez R, Alvarez JG. The sperm chromatin dispersion test: a simple method for the determination of sperm DNA fragmentation. J Androl. 2003;24:59-66. https://doi.org/10.1002/j.1939-4640. 2003.tb02641.x.

15. Enciso M, Lopez-Fernandez C, Fernandez JL, Garcia P, Gosalbez A, Gosalvez J. A new method to analyze boar sperm DNA fragmentation under bright-field or fluorescence microscopy. Theriogenology. 2006;65:308-16.

16. Esterhuizen AD, Franken DR, Lourens JG, Prinsloo E, van Rooyen LH. Sperm chromatin packaging as an indicator of invitro fertilization rates. Hum Reprod. 2000;200(15):657-61.

17. Virro MR, Larson-Cook KL, Evenson DP. Sperm chromatin structure assay (SCSA) parameters are related to fertilization, blastocyst development, and ongoing pregnancy in in vitro fertilization and intracytoplasmic sperm injection cycles. Fertil Steril. 2004;81:1289-95.

18. Alvarez Sedó C, Bilinski M, Lorenzi D, Uriondo H, Noblía F, Longobucco V, Lagar EV, Nodar F. Effect of sperm DNA fragmentation on embryo development: clinical and biological aspects. JBRA Assisted Reprod. 2017;21(4):343-50.

19. Nasr-Esfahani MH, Salehi M, Razavi S, Anjomshoa M, Rozbahani S, Moulavi F, Mardani M. Effect of sperm DNA damage and sperm protamine deficiency on fertilization and embryo development post-ICSI. Reprod BioMed Online. 2005 Aug;11(2):198-205. https://doi.org/10.1016/s1472-6483(10) 60959-5.

20. Fraczek M, Kurpisz M. The redox system in human semen and peroxidative damage of spermatozoa. Postepy Higieny i Medycyny Doswiadczalnej (Online). 2005;59:523-34.

21. Plante M, de Lamirande E, Gagnon C. Reactive oxygen species released by activated neutrophils, but not by deficient spermatozoa, are sufficient to affect normal sperm motility. Fertil Steril. 1994;62:387-93.

22. Gomez E, Buckingham DW, Brindle J, Lanzafame F, Irvine DS, Aitken RJ. Development of an image analysis system to monitor the retention of residual cytoplasm by human spermatozoa: correlation with biochemical markers of the cytoplasmic space, oxidative stress, and sperm function. J Androl. 1996;17:276-87.

23. Aziz N, Saleh RA, Sharma RK, et al. Novel association between sperm reactive oxygen species production, sperm morphological defects, and the spermsperm deformity index. Fertil Steril. 2004;81:349-54

24. Aitken RJ, Clarkson JS, Fishel S. Generation of reactive oxygen species, lipid peroxidation, and human sperm function. Biol Reprod. 1989;41:183-97.

25. Sies H. Strategies of antioxidant defense. Eur J Biochem. 1993;215:213-9.
26. Galecka E, Jacewicz R, Mrowicka M, Florkowski A, Galecki P. Enzymy antyoksydacyjne - budowa, właściwości, funkcje [Antioxidative enzymes - structure, properties, functions]. Pol Merkur Lekarski. 2008;25:266-8.

27. Peeker R, Abramsson L, Marklund SL. Superoxide dismutase isoenzymes in human seminal plasma and spermatozoa. Mol Hum Reprod. 1997;3:1061-6.

28. Scibior D, Czeczot H. Katalaza - budowa, właściwości, funkcje [Catalase: structure, properties, functions]. Postepy Hig Med Dosw (Online). 2006;60:170-80.

29. de Lamirande E, Leclerc P, Gagnon C. Capacitation as a regulatory event that primes spermatozoa for the acrosome reaction and fertilization. Mol Hum Reprod. 1997;3:175-94.

30. Fraga CG, Motchnik PA, Shigenaga MK, Helbock HJ, Jacob RA, Ames BN. Ascorbic acid protects against endogenous oxidative DNA damage in human sperm. Proc Natl Acad Sci U S A. 1991;88:11003-6.

31. Pfeifer H, Conrad M, Roethlein D, Kyriakopoulos A, Brielmeier $\mathrm{M}$, Bronkamm GW, et al. Identification of a specific sperm nucleinucleus selenoenzyme necessary for protamine thiol cross-linking during sperm maturation. FASEB J. 2001;15:1236-8.

32. Yeung $\mathrm{CH}$, Cooper TG, De Geyter M, De Geyter C, Rolf C, Kamischke A, Nieschlag E. Studies on the origin of redox enzymes in seminal plasma and their relationship with results of in-vitro fertilization. Mol Hum Reprod. 1998;4:835-9.

33. Valko M, Leibfritz D, Moncol J, Cronin MT, Mazur M, Telser J. Free radicals and antioxidants in normal physiological functions and human disease. Int J Biochem Cell Biol. 2007;39:44-84.

34. Oeda T, Henkel R, Ohmori H, Schill WB. Scavenging effect of $\mathrm{N}$-acetyl-L-cysteine against reactive oxygen species in human semen: a possible therapeutic modality for male factor infertility? Andrologia. 1997;29:125-31.

35. Etensel B, Ozkisacik S, Ozkara E, Karul A, Oztan O, Yazici M, Gursoy H. Dexpanthenol attenuates lipid peroxidation and testicular damage at experimental ischemia and reperfusion injury. Pediatr Surg Int. 2007;23:177-81.

36. Hogarth CA, Griswold MD. The key role of vitamin A in spermatogenesis. J Clin Invest. 2010;120:956-62.

37. Kessopoulou E, Powers HJ, Sharma KK, Pearson MJ, Russel JM, Cooke ID, et al. A double-blind randomized placebo crossover controlled trial using the antioxidant vitamin E to treat reactive oxygen species associated male infertility. Fertil Steril. 1995;64:825-31.

38. Keskes-Ammar L, Feki-Chakroun N, Rebai T, et al. Sperm oxidative stress and the effect of an oral vitamin $\mathrm{E}$ and selenium supplement on semen quality in infertile men. Arch Androl. 2003;49:83-94.

39. Lewin A, Lavon H. The effect of coenzyme Q10 on sperm motility and function. Mol Asp Med. 1997;18(Suppl):S213-9.

40. Mancini A, Conte B, De Marinis L, Hallgass ME, Pozza D, Oradei A, et al. Coenzyme Q10 levels in human seminal fluid: diagnostic and clinical implications. Mol Asp Med. 1994;15(Suppl):S249-55.

41. Zini A, Fischer MA, Nam RK, Jarvi K. Use of alternative and hormonal therapies in male infertility. Urology. 2004;63:141-3.

42. Roveri A, Casasco A, Maiorino M, Dalan P, Calligaro A, Ursini F. Phospholipid hydroperoxide glutathione peroxidase of rat testis. Gonadotropin dependence and immunocytochemical dentification. J Biol Chem. 1992;267:6142-6.

43. Alvarez JG, Storey BT. Lipid peroxidation and the reactions of superoxide and hydrogen peroxide in mouse spermatozoa. Biol Reprod. 1984;30:833-41.

44. Ursini F, Heim S, Kiess M, Maiorino M, Roveri A, Wissing J, et al. Dual function of the selenoprotein PHGPx during sperm maturation. Science. 1999;285:1393-6. 
45. Layek SS, Mohanty TK, Kumaresan A, Parks JE. Cryopreservation of bull semen: Evolution from egg yolk based to soybean based extenders. Anim Reprod Sci. 2016;172:1-9.

46. Noack-Fuller G, De Beer C, Seibert H. Cadmium, lead, selenium, and zinc in semen of occupationally unexposed men. Andrologia. 1993;25:7-12.

47. de Lamirande E, Gagnon C. Reactive oxygen species and human spermatozoa. I. Effects on the motility of intact spermatozoa and on sperm axonemes. J Androl. 1992;13:368-78.

48. Bilodeau JF, Blanchette S, Gagnon C, Sirard MA. Thiols prevent $\mathrm{H} 2 \mathrm{O} 2$-mediated loss of sperm motility in cryopreserved bull semen. Theriogenology. 2001;56:275-86.

49. Aurich JE, Schonherr U, Hoppe H, Aurich C. Effects of antioxidants on motility and membrane integrity of chilled-stored stallion semen. Theriogenology. 1997;48:185-92.

50. Son M, Lee M, Sung GH, Lee T, Shin YS, Cho H, Lieberman PM, Kang H. Bioactive activities of natural products against herpesvirus infection. J Microbiol. 2013;51:545-51.

51. Cooper TG, Noonan E, von Eckardstein S, Auger J, Baker HW, Behre HM, et al. World Health Organization reference values for human semen characteristics. Hum Reprod Update. 2010;16:231-45.

52. Cyrus A, Kabir A, Goodarzi D, Moghimi M. The effect of adjuvant vitamin $C$ after varicocele surgery on sperm quality and quantity in infertile men: a double blind placebo controlled clinical trial. Int Braz J Urol. 2015;41:230-8.

53. Thérond P, Auger J, Legrand A, Jouannet P. Alpha-tocopherol in human spermatozoa and seminal plasma: relationships with motility, antioxidant enzymes and leukocytes. Mol Hum Reprod. 1996;2:739-44.

54. Omu AE, Fatinikun T, Mannazhath N, Abraham S. Significance of simultaneous determination of serum and seminal plasma alpha-tocopherol and retinol in infertile men by high-performance liquid chromatography. Andrologia. 1999;31:347-54.

55. Greco E, Iacobelli M, Rienzi L, Ubaldi F, Ferrero S, Tesarik J. Reduction of the incidence of sperm DNA fragmentation by oral antioxidant treatment. J Androl. 2005;26:349-53.

56. Oda SS, El-Maddawy ZK. Protective effect of vitamin E and selenium combination on deltamethrin-induced reproductive toxicity in male rats. Exp Toxicol Pathol. 2012;64:813-9.

57. Adesiyan AC, Oyejola TO, Abarikwu SO, Oyeyemi MO, Farombi EO. Selenium provides protection to the liver but not the reproductive organs in an atrazine-model of experimental toxicity. Exp Toxicol Pathol. 2011;63:201-7.

58. Ourique GM, Saccol EMH, Pês TS, Glanzner WG, Schiefelbein SH, Woehl VM, Baldisserotto B, Pavanato MA, Gonçalves PBD, Barreto KP. Protective effect of vitamin E on sperm motility and oxidative stress in valproic acid treated rats. Food Chem Toxicol. 2016;2016(95):159-67.

59. Jacob RA, Pianalto FS, Agee RE. Cellular ascorbate depletion in healthy men. J Nutr. 1992;122:1111-8.

60. Fraga CG, Motchnik PA, Shigenaga MK, Helbock HJ, Jacob RA, Ames BN. Ascorbic acid protects against endogenous oxidative DNA damage in human sperm. PNAS. 1991;88:11003-6.

61. Nouri M, Ghasemzadeh A, Farzadi L, Shahnazi V, Ghaffari Novin M. Vitamins C, E and lipid peroxidation levels in sperm and seminal plasma of asthenoteratozoospermic and normozoospermic men. Iran J Reprod Med. 2008;6:1-5.

62. Rolf C, Cooper T, Yeung C, Nieschlag E. Antioxidant treatment of patients with asthenozoospermia or moderate oligoasthenozoospermia with high-dose vitamin $\mathrm{C}$ and vitamin $\mathrm{E}$ : a randomized, placebo-controlled, double-blind study. Hum Reprod. 1999; 14:1028-33.

63. Akmal M, et al. Improvement in human semen quality after oral supplementation of vitamin C. J Med Food. 2006;9(3):440-2.
64. Shi JZ, Zhang SS, Zhang Z, Liang Q, Shi Y, Hua JL, et al. Expressions of sperm-specific genes in carnitine-cultured testis sperm of obstructive azoospermia patients. Zhonghua Nan Ke Xue. 2010;16:504-9.

65. Banihani S, Agarwal A, Sharma R, Bayachou M. Cryoprotective effect of 1-carnitine on motility, vitality and DNA oxidation of human spermatozoa. Andrologia. 2014;46:637-41.

66. Waldner R, Lascan C, Lohninger A, Gessner M, Tuchler H, Huemer M, Spielgel W, Karlic H. Effects of doxorubicin-containing chemotherapy and combination with L-carnitine on oxidative metabolism in patients with non-hodgkin lymphoma. $\mathbf{J}$ Cancer Res Clin Oncol. 2006;132:121-8.

67. Vicari E, Vignera SL, Calogero AE. Antioxidant treatment with carnitines is effective in infertile patients with prostatovesiculoepididymitis and elevated seminal leukocyte concentrations after treatment with nonsteroidal anti-inflammatory compounds. Fertil Steril. 2002;78:1203-8.

68. Alshabanah OA, Hafez MM, Al-Harbi MM, Hassan ZK, Al R, Asiri YA, Sayed-Ahmed MM. Doxorubicin toxicity can be ameliorated during antioxidant L-Carnitine. Oxidative Med Cell Longev. 2010;3:428-33.

69. Abd-Elrazek AM, Ahmed-Farid OAH. Protective effect of L-carnitine and L-arginine against busulfan-induced oligospermia in adult rat. Andrologia. 2017;50(1):e12806. https:// doi.org/10.1111/and.12806.

70. Nazari L, Salehpour S, Hosseini S, et al. Effect of antioxidant supplementation containing L-carnitine on semen parameters: a prospective interventional study. JBRA Assist Reprod. 2021;25(1):76-80. Published 2021 Feb 2. https://doi.org/10. 5935/1518-0557.20200043.

71. Gressier B, Cabanis A, Lebegue S, Brunet C, Dine T, Luyckx $\mathrm{M}$, et al. Decrease of hypochlorous acid and hydroxyl radical generated by stimulated human neutrophils: comparison in vitro of some thiol-containing drugs. Methods Find Exp Clin Pharmacol. 1994;16:9-13.

72. Oeda T, Henkel R, Ohmori H, Schill WB. Scavenging effect of $\mathrm{N}$-acetyl-1-cysteine against reactive oxygen species in human semen: a possible therapeutic modality for male factor infertility? Andrologia. 1997;29:125-31.

73. Jannatifar R, Parivar K, Roodbari NH, et al. Effects of N-acetylcysteine supplementation on sperm quality, chromatin integrity and level of oxidative stress in infertile men. Reprod Biol Endocrinol. 2019;17:24.

74. Barekat F, Tavalaee M, Deemeh MR, et al. A Preliminary Study: $\mathrm{N}$-acetyl-L-cysteine Improves Semen Quality following Varicocelectomy. Int J Fertil Steril. 2016;10(1):120-6. https://doi.org/ 10.22074/ijfs.2016.4777.

75. Dragsted LO. Biomarkers of exposure to vitamins A, C, and E and their relation to lipid and protein oxidation markers. Eur $\mathbf{J}$ Nutr. 2008;47:3-18.

76. Barbato V, Talevi R, Braun S, Merolla A, Sudhakaran S, et al. Supplementation of sperm media with zinc, D-aspartate and co-enzyme Q10 protects bull sperm against exogenous oxidative stress and improves their ability to support embryo development. Zygote; Cambridge. 2017;25(2):168-75.

77. Isaac AV, Kumari S, Nair R, Urs DR, Salian SR, Kalthur G, Adiga SK, Manikkath J, Mutalik S, Sachdev D, Pasricha R. Supplementing zinc oxide nanoparticles to cryopreservation medium minimizes the freeze-thaw-induced damage to spermatozoa. Biochem Biophys Res Commun. 2017;494(3-4):656-62.

78. Kelkel M, Schumacher M, Dicato M, Diederich M. Antioxidant and anti-proliferative properties of lycopene. Free Radic Res. 2011;45:925-40.

79. Tvrdá E, Kováčik A, Tušimová E, et al. Antioxidant efficiency of lycopene on oxidative stress - induced damage in bovine spermatozoa. J Anim Sci Biotechnol. 2016;7:50. 
80. Majzoub A, Agarwal A. Systematic review of antioxidant types and doses in male infertility: Benefits on semen parameters, advanced sperm function, assisted reproduction and live-birth rate. Arab J Urol. 2017;16:113-24.

81. Rinaldi P, Polidori MC, Metastasio A, et al. Plasma antioxidants are similarly depleted in mild cognitive impairment and in Alzheimer's disease. Neurobiol Aging. 2003;24(7):915-9.

82. Mangialasche F, Kivipelto M, Mecocci P, et al. High plasma levels of vitamin $\mathrm{E}$ forms and reduced Alzheimer's disease risk in advanced age. J Alzheimers Dis. 2010;20(4):1029-37.

83. Akbaraly NT, Hininger-Favier I, Carrière I, et al. Plasma selenium over time and cognitive decline in the elderly. Epidemiology. 2007;18(1):52-8.

84. Arlt S, Müller-Thomsen T, Beisiegel U, Kontush A. Effect of oneyear vitamin $\mathrm{C}$ - and E-supplementation on cerebrospinal fluid oxidation parameters and clinical course in Alzheimer's disease. Neurochem Res. 2012;37(12):2706-14.

85. Galasko DR, Peskind E, Clark CM, et al. Antioxidants for Alzheimer disease: a randomized clinical trial with cerebrospinal fluid biomarker measures. Arch Neurol. 2012;69(7):836-41.
86. Tolonen M, Halme M, Sarna S. Vitamin E and selenium supplementation in geriatric patients. Biol Trace Elem Res. 1985;7(3):161-8.

87. Arruda RP, Silva DF, Alonso MA, Andrade AFC, Nascimento J, Gallego AM, Martins SMM, Granato TM. Nutraceuticals in reproduction of bulls and stallions. R Bras Zootec. 2010;39:393-400.

88. Stradaioli G, Sylla L, Zelli R, Chiodi P, Monaci M. Effect of L-carnitine administration on the seminal characteristics of oligoasthenospermic stallions. Theriogenology. 2004;62:761-77.

89. Stradaioli G, Sylla L, Zelli R, Verini SA, Chiodi P, Arduini A, Monaci M. Seminal carnitine and acetylcarnitine content and carnitine acetyltransferase activity in young Maremmano stallions. Anim Reprod Sci. 2000;64:233-45.

90. Ren F, Feng T, Dai G, Wang Y, Zhu H, Hu J. Lycopene and alphalipoic acid improve semen antioxidant enzymes activity and cashmere goat sperm function after cryopreservation. Cryobiology. 2018;84:27-32.

Publisher's Note Springer Nature remains neutral with regard to jurisdictional claims in published maps and institutional affiliations. 